\title{
PERAN TUHA PEUT DALAM PENGEMBANGAN REUSAM PERLINDUNGAN ANAK YANG BERHADAPAN DENGAN HUKUM (ABH) DI ACEH BESAR
}

\author{
Mansari \\ Fakultas Syari'ah dan Ekonomi Islam, \\ Universitas Iskandar Muda Banda Aceh \\ mansari_kaisar@ymail.com
}

\begin{abstract}
Some gampongs in Aceh Besar have established gampong reusam on child protection in written form. Reusam which usually regulates public behavior about habits undertaken by the public in an unwritten form, is now beginning to be written in written form. The formation of gampong reusam was formed by Tuha Peut Gampong which was discussed together with the keuchik and community leaders of the gampong. This research aims to find out how the process of reusam formation of child protection in Aceh Besar and how the role of Tuha Peut in determining the direction of development of child protection reusam in Aceh Besar. This research uses qualitative research with data source from primary data obtained through interview with Keuchik, Tuha Peut Gampong and Female Woman. Secondary data is obtained through documentation studies in the library. The results showed that the process of forming a village reusam on Child Protection was established through the involvement of elements and community leaders, even women were involved in the preparation. Tuha Peut has an important role in the development of a gampong reusam that adopts local and applicable local values in Aceh. These values are deliberation, mediation and the use of adat sanctions for child offenders in cases that occur, such as Advice, Warning, apology, fines, compensation, returned to the family, Establishment of Child Protection Committees dealing with law and engagement government agencies.
\end{abstract}

Keywords: reusam gampong, $A B H$, child protection 


\begin{abstract}
Abstrak
Beberapa gampong (desa) di Aceh Besar telah membentuk reusam gampong tentang perlindungan anak dalam bentuk tertulis. Reusam yang biasanya mengatur tingkah laku masyarakat tentang kebiasaan-kebiasan yang dilakukan oleh masyarakat dalam bentuk tidak tertulis, saat ini mulai dituliskan dalam bentuk tertulis. Pembentukan reusam gampong dibentuk oleh Tuha Peut Gampong yang dibahas secara bersama-sama dengan keuchik dan tokoh-tokoh masyarakat gampong. Penelitian in bertujuan untuk mengetahui bagaimana proses pembentukan reusam perlindungan anak di Aceh Besar dan bagaimana peran Tuha Peut dalam menentukan arah pengembangan reusam perlindungan anak di Aceh Besar. Penelitian ini menggunakan penelitian kualitatif dengan sumber datanya dari data primer yang diperoleh melalui wawancara dengan Keuchik, Tuha Peut Gampong dan Tokoh Perempuan. Data sekunder diperoleh melalui studi dokumentasi di perpustakaan. Hasil penelitian menunjukkan bahwa proses pembentukan reusam gampong tentang Perlindungan Anak dibentuk melalui pelibatan unsur-unsur dan tokoh masyarakat, bahkan perempuan turut dilibatkan dalam penyusunannya. Tuha Peut memiliki peran penting dalam pengembangan reusam gampong yang mengadopsi nilai-nilai lokal yang berlaku dan diterapkan di Aceh. Nilai-nilai tersebut adalah adanya musyawarah, mediasi dan penggunaan sanksi adat bagi pelaku anak dalam kasus-kasus yang terjadi, seperti nasehat, teguran, permintaan maaf, denda, ganti kerugian, dikembalikan kepada keluarga, pembentukan Komite Perlindungan Anak yang berhadapan dengan hukum dan pelibatan instansi pemerintah.
\end{abstract}

Kata Kunci: reusam gampong, $\mathrm{ABH}$, perlindungan anak

\section{PENDAHULUAN}

Pengaturan mengenai perlindungan anak mengalami pesat dibandingkan sebelum disahkannya UU Nomor 11 Tahun 2012 tentang Sistem Peradilan Pidana Anak. Kehadiran UU tersebut memberikan warna baru dalam konteks penanganan anak yang berhadapan dengan hukum. Ketentuan baru yang diatur dalam UU tersebut adalah adanya restorative justice dan diversi yang tidak pernah ditemukan dalam UU Nomor 3 Tahun 1997 tentang Pengadilan Anak. Restorative justice merupakan penyelesaian perkara tindak pidana dengan melibatkan pelaku, korban, keluarga pelaku/korban, dan pihak lain yang terkait untuk bersama-sama mencari penyelesaian yang adil dengan menekankan pemulihan kembali pada keadaan semula, dan bukan pembalasan. Sedangkan diversi merupakan pengalihan penyelesaian perkara anak dari proses peradilan pidana ke proses di luar peradilan pidana.

Kedua istilah ini sebenarnya bagi masyarakat Aceh kurang mengetahuinya, bahkan relatif asing. Namun, secara substansial yang terdapat dalam kedua konsep tersebut telah dipraktekkan sejak lama oleh masyarakat Aceh dalam kehidupannya. Masyarakat Aceh telah terbiasa dengan menyelesaikan permasalahan yang termasuk dalam kategori perselisihan kecil yang terjadi dalam kehidupannya dengan model 
penyelesaian perkara di luar peradilan. Istilah yang sering digunakan oleh masyarakat dengan sebutan penyelesaian secara adat.

BeberapagampongdiAceh Besar telah mengembangkan konsep penanganan anak yang berhadapan dengan hukum melalui reusam gampong. Menurut Kamus Umum Bahasa Aceh-Indonesia, reusam adalah suatu kebiasaan, adat istiadat di suatu daerah atau beberapa tata cara kehidupan (Pusat Bahasa Departemen Pendidikan Nasional, 2011: 800). Salah satu karakteristik dari adat adalah tidak diwujudkan dalam bentu tertulis. Menurut Ishaq, hukum kebiasaan terdapat kelemahan-kelemahan, sebab tidak dirumuskan secara jelas dan pada umumnya sukar digali dikarenakan tidak tertulis dan beraneka ragam sehingga tidak menjamin adanya kepastian hukum (Ishaq, 2014: 46).

Reusam yang sebenarnya tidak diwujudkan dalam bentuk tertulis, saat ini khusus reusam yang mengatur tentang Perlindungan Anak sudah mulai dituliskan oleh beberapa gampong di Aceh Besar. Aturan tersebut merupakan pengembangan dari UU yang mengatur tentang Perlindungan Anak dan Sistem Peradilan Pidana Anak yang disesuaikan dengan konteks lokal dan nilai-nilai budaya yang hidup dan berkembang dalam masyarakat. Pembentukan tersebut tidak terlepas dari keterlibatan Tuha Peut sebagai Lembaga Adat Aceh yang diberikan kewenangan untuk merumuskan tentang aturan dalam gampong. Pasal 44 Ayat (1) Qanun Aceh Besar Nomor 11 Tahun 2009 tentang Pemerintahan Gampong menentukan Tuha Peuet Gampong mempunyai fungsi menetapkan Qanun Gampong dan peraturan lainnya bersama Keuchik serta menampung dan menyalurkan aspirasi masyarakat.

Pergeseran dari aturan yang sebenarnya tidak tertulis, kemudian diatur dalam bentuk aturan tertulis sangat menarik dikaji dalam konteks sosiologi hukum. Penelitian ini bertujuan mengkaji tentang bagaimana proses pembentukan reusam perlindungan anak di Aceh Besar dan bagaimana peran Tuha Peut dalam menentukan arah pengembangan reusam perlindungan anak di Aceh Besar. Untuk itu, penelitian ini diberi judul dengan "Peran Tuha Peut dalam Pengembangan Reusam Perlindungan Anak yang Berhadapan dengan Hukum di Aceh Besar".

\section{METODOLOGI PENELITIAN}

Penelitian ini termasuk penelitian kualitatif yang bertujuan untuk mendeskripsikan partisipasi perempuan dalam penyusunan reusam di Aceh Besar. Instrumen pengumpulan data dilakukan dengan cara melakukan wawancara secara mendalam (depth interview) dengan tokoh masyarakat, yaitu Keuchik dan tokoh perempuan gampong. Selain itu, wawancara dilakukan dengan tim pendamping dari Pusat Kajian Pendidikan dan Masyarakat (PKPM) Aceh. Lokasi penelitian di lakukan di dua gampong yaitu gampong Neusok Kecamatan Darul Kamal dan Gampong Lambirah Kecamatan Suka Makmur.

\section{TEMUAN PENELITIAN}

\section{A. Proses Penyusunan Reusam Gampong di Aceh Besar}

Penyusunan reusam perlindungan anak merupakan salah satu usaha yang dilakukan oleh beberapa gampong di 
Aceh Besar untuk menuliskan menjadi aturan hukum tertulis bagi masyarakat dalam mengatur tentang hak-hak yang seharusnya didapatkan oleh anak dalam menunjang dan menjamin kehidupannya menjadi lebih baik. Sebenarnya konsep reusam yang dipraktekkan oleh masyarakat Aceh terdahulu tidak pernah menuliskannya dalam bentuk tertulis. Akan tetapi reusam hanya mengatur tata kehidupan masyarakat yang dipraktekkan secara turun temurun terhadap suatu persoalan tertentu dalam bentuk tidak tertulis.

Beberapa referensi menyebutkan bahwa reusam merupakan aturan yang tidak tertulis. Menurut Kamus Umum Bahasa Aceh-Indonesia, reusam adalah suatu kebiasaan, adat istiadat di suatu daerah atau beberapa tata cara kehidupan (Pusat Bahasa Departemen Pendidikan Nasional, 2011: 800). Badruzzaman, mendefinisikan reusam dengan tatanan protokoler/seremonial adat istiadat dari ahli-ahli adat yang terus berjalan. Sedangkan menurut Rusdi Sufi, reusam adalah aturan tentang beberapa segi kehidupan manusia yang tumbuh dalam suatu daerah yang tertentu sebagai kelompok sosial yang mengatur tata tertib tingkah laku anggota masyarakat. Aturan-aturan tentang segi kehidupan manusia itu menjadi aturan hukum yang mengikat dan kemudian disebut adat (Rusdi Sufi, 2002: 40).

Berbagai definisi tersebut tidak menjelaskan bahwa reusam dalam bentuk tertulis. Akan tetapi reusam adalah kebiasaan dan adat istiadat yang dilakukan oleh masyarakat. Hakikat dari hukum adat sebenarnya tidak tertulis yang berbeda dengan produk peraturan perundangundangan. Ketentuan peraturan perundang-undangan memiliki ciri khas tersendiri yaitu tertulis secara sistematis dan tersusun dalam bentuk pasal per pasal.

Meskipun reusam sebenarnya tidak tertulis, namun beberapa gampong diAceh Besar yang telah mulai menuliskannya dalam bentuk tertulis. Terdapat enam gampong yang mengatur tentang perlindungan anak yang merupakan gampong dampingan LSM Pusat Kajian Pendidikan dan Masyarakat, yaitu:

1. Gampong Neuheun Kecamatan Mesjid Raya

2. Gampong Lam Ujong Kecamatan Baitussalam

3. Gampong Bineh Blang Kecamatan Ingin Jaya

4. Gampong Meunasah Tutong Kecamatan Ingin Jaya

5. Gampong Lambirah Kecamatan Suka Makmur, dan

6. Gampong Neusok Kecamatan Darul Kamal

Pusat Kajian Pendidikan dan Masyarakat Aceh yang didukung oleh UNICEF sejak tahun 2015 sampai dengan 2017 telah berhasil mendapatkan out put yang maksimal dari program yang dikembangkan yaitu Penguatan Perlindungan Anak dan Pencatatan Kelahiran Anak. Perlindungan Anak diperuntukkan kepada anak yang berhadapan dengan hukum yang dikhususkan di wilayah Aceh Besar. Sementara pencatatan kelahiran dilaksanakan pada empat gampong di Banda Aceh, yaitu Lueng Bata, Pango Raya, Lhong Raya dan Lamgugob. Sedangkan di Aceh Besar hanya dua gampong yaitu Gampong Lam Ujong 
dan Gampong Meunasah Tutong.

Khusus mengenai anak yang berhadapan dengan hukum telah dibentuk reusam dengan tujuan supaya sedapat mungkin anak-anak yang berhadapan dengan hukum tidak dibawa ke ranah peradilan formal. Di samping itu, dengan adanya reusam tersebut dapat mendorong aparatur gampong supaya dapat menfasilitasi proses penyelesaian kasus-kasus anak dengan cara menggunakan kearifan lokal dan budaya penyelesaian kasus secara mediasi komunitas.

Proses penyusunan reusam dibentuk dengan cara melibatkan berbagai unsur dan lapisan masyarakat. Tokohtokoh gampong yang terdiri dari cerdik pandai, tokoh agama, tokoh adat dan tokoh perempuan, bahkan anak-anak pun dilibatkan dalam penyusunannya. Pelibatan semua unsur yang ada dalam masyarakat supaya dapat mewakili kepentingannya masing-masing. Semua pihak yang hadir diperbolehkan menyampaikan aspirasinya. Pandangan yang disampaikan bukan tanpa adanya filterisasi, akan tetapi dimusyawarahkan terlebih dahulu sebelum ditetapkan dalam pasal demi pasal.

Dalam diskusi dan pembahasan setiap pasal yang diajukan seringkali adanya perbedaan pendapat antara satu orang dengan orang yang lain. Fenomena ini tidak asing lagi bagi negara yang menganut sistem demokrasi. Di mana setiap orang diberikan kebebasan untuk menyampaikan pendapatnya meskipun kadangkala berseberangan dengan pendapat yang diajukan oleh pihak lain (Manshurdin: Keuchik, wawancara). Menurut Rohani, anggota Tuha Peut Gampong Neusok, ketika pembahasan apapun yang dilakukan di meunasah memang tidak dapat dihindari dari banyaknya tanggapan yang disampaikan oleh masyarakat. Akibat dari banyaknya komentar dan masukan yang diberikan, tidak jarang diskusi berakhir hingga tengah malam (Rohani, Tuha Peut, wawancara).

Dalam konteks penyusunan reusam gampong yang mengatur tentang perlindungan anak juga terjadi hal yang sama.Palingtidakdenganadanyamasukan tersebut dapat mewakili kepentingankepentingan bagi perempuan. Misalnya salah satu masukan yang disampaikan adalah menyangkut dengan partisipasi perempuan dalam penanganan anak yang berhadapan dengan hukum. Dalam draft awal yang telah disusun oleh tim dari Pusat Kajian Pendidikan dan Masyarakat (PKPM) tidak menyebutkan secara tegas tentang keterwakilah tokoh perempuan. Dalam pertemuan pembahasan reusam terjadilah diskusi yang sangat ketat terkait dengan perwakilan perempuan dalam penanganan $\mathrm{ABH}$. Akhirnya, melalui diskusi panjang dimasukkan klausul tersebut menjadi salah satu dasar bagi perempuan untuk terlibat aktif dalam menangani setiap kasus anak (Rohani: Tuha Peut, wawancara).

Draft reusam yang telah dibentuk merupakan awal dari aturan yang membutuhkan diskusi panjang bagi masyarakat. Draft tersebut dibagikan secarasamadisetiapgampongdampingan PKPM. Namun setelah dibahas dan didiskusikan secara bersama-sama di tingkat gampong, adanya perbedaanperbedaan pengaturan yang disepakati bersama. Salah satu contohnya adalah tentang pelibatan perempuan dalam penanganan $\mathrm{ABH}$ yang tidak disebutkan 
secara tegas dalam reusam Gampong Lambirah dan Gampong Neuheun. Akan tetapi hanya ditemukan di Gampong Neusok Kecamatan Darul Kamal (Firdaus D. Nyak Idin: Fasilitator PKPM, wawancara).

Menurut Sukardi, Keuchik Gampong Lambirah, masuk atau tidaknya suatu pengaturan dalam reusam sangat ditentukan oleh peran aktif masyarakat. Pada saat diskusi pembahasan reusam gampong, Tuha Peut memandu diskusi dan memberikan pandanganpandangannya terkait penyempurnaan aturan yang akan ditetapkan. Masyarakat yang kritis turut mempengaruhi produk reusam yang dihasilkan. Sebaliknya, masyarakat yang pasif berimplikasi pada aturan yang cenderung apa adanya dan tidak adanya inovasi-inovasi baru yang dapat dikembangkan (Sukardi: Keuchik, wawancara).

Penyusunan reusam dilakukan pada malam hari selama lima sampai enam kali pertemuan. Undangannya disampaikan pada setiap akhir pertemuan. Selain itu juga diinformasikan kembali pada malam menjelang kegiatan untuk mengingatkan kepada masyarakat supaya dapat menghadirinya dalam jumlah yang banyak. Pada setiap pembahasan reusam selalu difasilitasi oleh tim dari PKPM. Sebelum melaksanakan kegiatan pada malam hari, PKPM telah memberikan pemahaman kepada masyarakat dari beberapa gampong dampingan terkait substansi yang akan diatur reusam tersebut.

Isu perlindungan anak yang diberikan sangat bervariasi. Selain dibekali mengenai proses penyelesaian secara adat juga topik-topik lainnya. Seperti pembahasan tentang Konvensi Hak
Anak, Psikologi Anak dalam Keluarga, Pemulihan Psikososial Anak pasca menjalani mekanisme penyelesaiannya, perlindungan anak dalam perspektif adat budaya Aceh, perlindungan anak dalam perspektif Islam, pentingnya pencatatan kelahiran bagi anak dan lain sebagainya.

\section{B. Arah Pengembangan Reusam Perlindungan Anak di Gampong}

Salah satu kewenangan Tuha Peut sebagai lembaga adat Aceh yang masih eksis hingga sekarang adalah membentuk Qanun Gampong. Pasal 44 Ayat (1) Qanun Aceh Besar Nomor 11 Tahun 2009 tentang Pemerintahan Gampong menentukan Tuha Peuet Gampong mempunyai fungsi menetapkan Qanun Gampong dan peraturan lainnya bersama Keuchik serta menampung dan menyalurkan aspirasi masyarakat.

Ketentuan tersebut menjadi landasan yuridis bagi Tuha Peut dalam menyusun Qanun Gampong untuk mengatur kehidupan tingkah laku masyarakat dalam berbagai dimensi kehidupan, termasuk mengatur tentang perlindungan anak. Reusam gampong tentang perlindungan anak yang diatur oleh Tuha Peut merupakan penjabaran lebih lanjut dari UU Nomor 11 Tahun 2012 tentang Sistem Peradilan Pidana Anak dalam konteks penyelesaian anak yang berhadapan dengan hukum.

Istilah yang digunakan dalam UU Nomor 11 Tahun 2012 adalah restorative justice dan diversi. Mayoritas masyarakat pertama sekali ketika istilah itu diperkenalkan belum familiar dengannya. Bahkan sebagian dari mereka baru mendengarkan istilah tersebut. Sebenarnya substansi restorative justice 
dan diversi telah dipraktekkan sejak lama oleh masyarakat Aceh melalui mediasi komunitas.

Substansi dari restorative justice dan diversi adalah menyelesaikan perkara melalui jalur di luar pengadilan dengan melibatkan beberapa unsur terkait. Begitu juga dengan proses penyelesaian perkara dalam masyarakat Aceh dilakukan dengan melibatkan pihak ketiga sebagai pihak yang bersifat netral dan imparsial serta melibatkan pelaku dan korban. Pihak ketiga ini berasal dari lembaga adat gampong yaitu Keuchik, Tuha Peut Gampong, Imeum Gampong. Bila perkara tersebut kecil biasanya tidak diselesaikan melalui peradilan adat gampong, akan tetapi dapat dilakukan mediasi di rumah keuchik maupun di rumah pihak yang berperkara.

Usaha melibatkan pelaku dan korban guna mencarikan solusi pemecahan perselisihan dan konflik masyarakat menjadi karakteristik utama dari konsep restorative justice dan diversi sebagaimana yang dimaksudkan dalam peraturan perundang-undangan. Pasal 1 Ayat (6) UU Nomor 11 Tahun 2012 tentang Sistem Peradilan Pidana menyatakan bahwa Keadilan Restoratif adalah penyelesaian perkara tindak pidana dengan melibatkan pelaku, korban, keluarga pelaku/korban, dan pihak lain yang terkait untuk bersama-sama mencari penyelesaian yang adil dengan menekankan pemulihan kembali pada keadaan semula, dan bukan pembalasan.

Pengembangan reusam gampong tentang perlindungan anak yang dibentuk di Gampong Neusok dan Gampong Lambirah diwujudkan dalam beberapa bentuk, yaitu:

\section{Penyelesaian Secara Adat Melalui Budaya Masyarakat Aceh}

Nilai yang diadopsi dalam reusam perlindungan anak adalah mengakomodir budaya dan kearifan lokal yang dimiliki oleh masyarakat Aceh yang dipraktekkan secara turun temurun. Menurut Pasal 8 Ayat 4 Reusam Gampong Lambirah tentang Perlindungan Anak Bermasalah dengan Hukum bahwa sistem peradilan melalui mekanisme adat harus memperhatikan hak anak dan menerapkan prinsip keadilan restoratif yang bertujuan untuk memperbaiki anak bukan bertujuan untuk penghukuman.

Ketentuan ini merupakan penjabaran lebih lanjut mengenai restorative justice dalam UU Sistem Peradilan Pidana Anak. Namun ketentuan dalam reusam lebih menekankan pada penyelesaian secara adat sesuai dengan konteks masyarakat Aceh. Pihak yang dilibatkan dalam konsep Keadilan restoratif dalam UU Sistem Peradilan Pidana Anak sebagaimana diatur dalam Pasal 8 adalah Anak dan orang tua/Walinya, korban dan/ atau orang tua/Walinya, Pembimbing Kemasyarakatan, dan Pekerja Sosial Profesional berdasarkan pendekatan Keadilan Restoratif. Sementara dalam Reusam mengatur tentang penyelesaian melalui mekanisme adat. Penyelesaian secara peradilan adat yang akan bertindak sebagai ketua sidang Keuchik, dan hakim anggotanya adalah Tuha Peut dan imeum gampong.

Bagi masyarakat Aceh, terdapat 18 kasus adat yang dapat diselesaikan melalui peradilan adat, sebagaimana yang diatur dalam Pasal 13 Qanun Aceh Nomor 9 Tahun 2008 tentang Pembinaan Kehidupan Adat Istiadat, 
yaitu: perselisihan dalam rumah tangga; sengketa antara keluarga yang berkaitan dengan faraidh; perselisihan antar warga; khalwat meusum; perselisihan tentang hak milik; pencurian dalam keluarga (pencurian ringan); perselisihan harta sehareukat; pencurian ringan; pencurian ternak peliharaan; pelanggaran adat tentang ternak, pertanian, dan hutan; persengketaan di laut persengketaan di pasar; penganiayaan ringan; pembakaran hutan (dalam skala kecil yang merugikan komunitas adat); pelecehan, fitnah, hasut, dan pencemaran nama baik; pencemaran lingkungan (skala ringan); ancam mengancam (tergantung dari jenis ancaman); dan perselisihan-perselisihan lain yang melanggar adat dan adat istiadat.

Dalam proses pemeriksaan perkara yang diselesaikan oleh lembaga adat memiliki asas-asas yang terkandung di dalamnya, yaitu (T. Djuned: Majelis Adat Aceh, 13): Pertama, pemeriksaan perkara dilakukan melalui proses thesa, antithesa dan sinthesa. Asas tersebut menggambarkan bahwa kedudukan para pihak dalam proses penyelesaian perkara sama. Kesempatan yang sama diberikan untuk menyampaikan segala hal-hal yang mendukung dalam pemeriksaan perkara. Asas ini sama dengan asas yang terdapat dalam proses penyelesaian perkara pada umumnya yaitu asas "equality before the law".

Kedua, peradilan dilaksanakan dengan hakim kolegial, yang dilaksanakan oleh fungsionaris adat yang diberi kedudukan sebagai hakim, terdiri dari Keuchik, Teungku Meunasah dan Tuha Peut. Mereka bertindak sebagai hakim dalam menyelesaikan perkara di samping sebagai pejabat di tingkat Gampong yang menjalankan roda pemerintahan. Ketiga, hukum harus ditegakkan dan memperhatikan supaya terhindar dari perpecahan dalam masyarakat. Hal ini diwujudkan dalam hadih madja Aceh "Uleu beu matee ranteng bek patah". Artinya dalam menyelesakan perkara harus diselesaikan sampai ke akar-akarnya, namun di antara mereka tidak ada yang dirugikan. Kedua-duanya mendapatkan posisinya yang sama tanpa dibedakan kedudukan dan jabatannya.

Keempat, penyelesaian diwujudkan dalam bentuk perdamaian. Artinya, keinginan yang ingin diwujudkan dalam proses penyelesaian perkara adalah terwujudnya perdamaian bagi para pihak. Hadih madja Aceh yang menerangkan tentang itu adalah "tatarek panyang talingkang paneuk". Artinya, suatu persoalan bila ingin diperbesar, maka persoalannya akanmenjadi besar. Sebaliknya, bila persolan ingin diselesaikan secara cepat, maka proses perkaranya akan menjadi lebih singkat. Oleh karenanya, kedua belah pihak perlu menanamkan rasa saling mengalah supaya usaha mendamaikannya berjalan secara maksimal.

Kelima, penyelesaian perkara pidana dilakukan secara formal dan material. Asas ini mengandung ajaran bahwa penyelesaian suatu sengketa dikehendaki dan ditujukan untuk memperbaiki segala sesuatu yang telah rusak akibat terjadinya kasus. Perbaikan itu tidak hanya dilakukan dengan penyelesaian dan penjatuhan sanksi adat kepada pihak yang salah, tapi disertai dengan beban materil. Wujudnya dapat dilakukan dalam bentuk permintaan maaf, peusijuek dan pemberian ganti rugi kepada korban atau ahli warisnya dalam hal korban meninggal dunia.

Jika terjadinya kasus pidana yang 
berkaitan dengan jiwa dan anggota badan, cara penyelesaiannya dikenal dengan istilah sayam dan suloh. Sayam merupakan kompensasi berupa harta yang diberikan oleh pelaku pidana terhadap korban atau ahli waris korban, dalam hal anggota badan rusak atau tidak berfungsi atau dikenal juga dengan kompensasi dari keluarnya darah seseorang akibat penganiayaan. Sedangkan suloh dipahami sebagai upaya perdamaian (al-shulhu) antara pelaku pidana dan pihak korban. Suloh tidak hanya diberlakukan terhadap kasus pencederaan anggota badan, tetapi juga terhadap tindak pidana menghilangkan nyawa orang lain. Oleh karenanya, Suloh merupakan pendekatan dan langkah awal terwujudnya diyat dan sayam. Melalu metode suloh dapat diawali upaya mencari kerelaan dan kemanfaatan dari korban dan ahli warisnya, sehingga ia bersedia dengan tulus menerima pembayaran diyat dan sayam (Rusydi Ali Muhammad \& Dedi Sumardi: Dinas Syariat Islam Aceh, 49-50).

\section{Pemberian Sanksi yang Bersifat Mendidik}

Sanksi yang diberikan kepada anak yang melakukan pelanggaran hukum adalah dengan memberikan hukuman yang bersifat mendidik. Seperti nasehat, teguran, pernyataan permintaan maaf, denda, ganti kerugian, dikembalikan kepada keluarga dan masyarakat untuk pembinaan, tinggal diDayahatau lembaga sejenisnya untuk belajar dalam beberapa waktu tertentu, membersihkan meunasah atau masjid atau fasilitas umum lainnya di gampong, menjadi Mu'azzin di Masjid atau Meunasah selama beberapa waktu tertentu, menghafal Juz 'Amma dalam jumlah tertentu, anak dipindahkan dari gampong asal ke tempat lain yang lebih kondusif dan aman bagi anak karena pertimbangan tertentu dengan ketentuan tempat tersebut adalah keluarga, seagama, dan seadat.

Terdapat beberapa alasan yang mendukung bahwa anak tidak perlu dihukum dengan hukuman yang berat, yaitu:

Pertama, anak-anak belum mempunyai kematangan berfikir, sehingga belum sepenuhnya mampu berpikir mana yang selayaknya tidak boleh dan sebaliknya. Kedua, anak-anak sering melakukan sesuatu karena ikut-ikutan tanpa mampu memikirkan akibatnya. Ketiga, anak-anak sering melakukan sesuatu karena memperoleh contoh-contoh yang tidak baik di lingkungannya. Keempat, kesalahan yang dilakukan oleh anakanak kadangkalanya lebih disebabkan oleh kelalaian orang tua dalam membina dan kelalaian Pemerintah dalam menjaga kondisi lingkungan yang kondusif untuk mendukung pertumbuhan dan perkembangan mental dan perilaku anak. Kelima, anak-anak masih mempunyai masa depan panjang yang harus mendapat dukungan semua pihak untuk pencapaiannya (Badruzzaman Ismail, Majelis Adat Aceh, 38-39).

\section{Pembentukan Komite Perlindungan dan Penanganan Anak Berhadapan dengan Hukum}

Pembentukan Komite Perlindungan Anak dalam penanganan anak berhadapan dengan hukum memiliki urgensi penting untuk mengontrol penanganan $\mathrm{ABH}$ secara maksimal. Komponen yang dilibatkan dalam komite perlindungan anak terdiri dari berbagai unsur, yaitu unsur masyarakat, 
tokoh agama, tokoh perempuan, dan forum anak. Pasal 12 Ayat (1) Reusam Gampong Neusok Nomor 07/12/2016 tentang Pembinaan Kehidupan Anak di Gampong Neusok menyatakan bahwa Pemerintah Gampong berkewajiban membentuk komite untuk perlindungan dan penanganan anakberhadapandengan hukum. Selanjutnya Ayat (2) dinyatakan bahwa dalam membentuk komite, Pemerintah Gampong harus melibatkan tokoh masyarakat, tokoh perempuan, Kepemudaan dan Forum Anak. Hal yang sama diatur dalam Reusam Gampong Lambirah Nomor 01/LB/X/2016 tentang Perlindungan Anak Bermasalah dengan Hukum sebagaimana terdapat dalam Pasal 12 Ayat (1) yang menyatakan aparat gampong berkewajiban membentuk komite untuk perlindungan dan penanganan anak berhadapan dengan hukum. Selanjutnya dalam Ayat (2) dinyatakan dalam membentuk komite, aparat gampong harus melibatkan unsur masyarakat, tokoh agama, tokoh perempuan dan forum anak.

Kewajiban Pemerintah Gampong dalam membentuk Komite Perlindungan Anak yang berhadapan dengan hukum merupakan suatu hal yang sangat penting. Keberadaannya pada tingkat gampong bertujuan untuk mengawasi dan mengontrol pelaksanan perlindungan dan penanganan yang berhadapan dengan hokum sampai berakhir. Menurut Yusri, Tuha Peut Gampong Lambirah, dengan adanya komite ini diharapkan akan terpenuhinya hak-hak anak yang berhadapan dengan hokum serta terlindungi identitasnya.

\section{Pelibatan Lembaga Pemerintah dalam Penanganan ABH di Tingkat Gampong}

Kemajuan lainnya yang dikembangkan dalam Reusam Gampong tentang perlindungan anak adalah memberikan kesempatan kepada instansi pemerintah seperti Lembaga PenyelenggaraanKesejahteraanSosialdan Tenaga Kesejahteraan Sosial Kecamatan. Menurut Manshurdin, keterlibatan lembaga tersebut dapat dimungkin bila diperlukan. Apabila dengan sumber daya manusia yang ada di gampong dapat teratasi dengan baik, maka tidak akan diundang. Semuanya membutuhkan koordinasi dan pertimbangan yang matang dalam melibatkannya. Tujuan yang ingin diwujudkan adalah dapat terwujudnya kepetingan terbaik bagi anak (Manshurdin: Keuchik, wawancara).

Bahkan menurut Yusri (Yusri: Tuha Peut, wawancara), Dayah pun dapat dilibatkan bila dibutuhkan. Oleh karena itu, dalam reusam diatur keterlibatannya sebagaimana diatur dalam Pasal 13 Ayat (4) yang menyatakan keuchik dan aparat gampong jika diperlukan bisa melibatkan lembaga keagamaan seperti, Dayah maupun Kantor Urusan Agama.

\section{SIMPULAN}

Berdasarkan permasalahan sebagaimana yang dideskripsikan di atas, dapat disimpulkan bahwa penyusunan reusam gampong tentang perlindungan anak di Aceh Besar dilakukan di enam gampong yang merupakan gampong dampingan PKPM Aceh atas dukungan UNICEF, yaitu Gampong Neuheun Kecamatan Mesjid Raya, Gampong Lam Ujong Kecamatan Baitussalam 
Gampong Bineh Blang Kecamatan Ingin Jaya, Gampong Meunasah Tutong Kecamatan Ingin Jaya Gampong Lambirah Kecamatan Suka Makmur dan Gampong Neusok Kecamatan Darul Kamal. Proses penyusunannya dilakukan dengan melibatkan berbagai unsur masyarakat, yaitu tokoh agama, tokoh adat, tokoh perempuan, tokoh cerdik pandai di gampong dan anak. Pembahasannya dilakukan dengan membahas pasal per pasal draft reusam yang telah dipersiapkan oleh tim PKPM Aceh. Peserta yang hadir diberikan kesempatan untuk mengutarakan pendapatnya masing-masing, kemudian didiskusikan secara bersama-sama. Tuha Peut Gampong memiliki peran penting dalam pengembangan reusam perlindungan anak. Selain memandu diskusi pada saat pembahasan reusam, juga turut memberikan pandangannya dalam penyempurnaan reusam tersebut. Pengembangan reusam perlindungan anak dalam konteks penanganan anak yang berhadapan dengan hukum dapat dilihat dengan pencantuman keterwakilan perempuan sebagai pihak yang berperan aktif dalam penyelesaian kasus-kasus anak yang berhadapan dengan hukum dan pengembanganpengembangan lainnya, yaitu: Pertama, mengedepankan nilai-nilai adat dan budaya yang hidup dan berkembang dalam masyarakat. Kedua, mengupayakan semaksimal mungkin kasus-kasus anak yang melakukan tindak pidana dan pelanggaran lainnya tidak dibawakan kepada ranah formal (criminal justice system), akan tetapi lebih memprioritaskan menggunakan mekanisme peradilan adat. Ketiga, memberikan hukuman kepada anak sebagai hukuman yang bersifat mendidik dan pembinaan supaya ia tidak mengulanginya kembali. Seperti nasehat, teguran, pernyataan permintaan maaf, denda, ganti kerugian, dikembalikan kepada keluarga dan masyarakat untuk pembinaan, tinggal di Dayah atau lembaga sejenisnya untuk belajar dalam beberapa waktu tertentu, membersihkan meunasah atau masjid atau fasilitas umum lainnya di gampong, menjadi Mu'azzin di Masjid atau Meunasah selama beberapa waktu tertentu, menghafal Juz 'Amma dalam jumlah tertentu, anak dipindahkan dari gampong asal ke tempat lain yang lebih kondusif dan aman bagi anak karena pertimbangan tertentu dengan ketentuan tempat tersebut adalah keluarga, seagama, dan seadat. Pembentukan Komite Perlindungan dan penanganan Anak yang Berhadapan dengan Hukum dan pelibatan instansi pemerintah seperti LPKS, Puspelkessos dan Tenaga Kesejahteraan Sosial Kecamatan.

Berdasarkan

pembahasan sebagaimana yang dipaparkan di atas, disarankan kepada gampong-gampong lain di wilayah Aceh Besar khususnya, dan Aceh pada umumnya mereplikasikan reusam gampong yang telah ditetapkan. Ketentuan tersebut memiliki arti penting bagi anak supaya anak-anak tidak langsung dibawakan kepada mekanisme formal sebelum diselesaikan dengan menggunakan mekanisme adat. Disarankan juga kepada MAA untuk terus menerus memberikan penguatan kepada tokoh-tokoh adat di tingkat gampong tentang penyelesaian perkara secara peradilan adat dan perlu memperkuat strategi mediasi kasus supaya dapat menghasilkan hasil yang maksimal. 


\section{DAFTAR PUSTAKA}

Pusat Bahasa Departemen Pendidikan Nasional, Kamus Bahasa AcehIndonesia, Depdiknas, Jakarta: 2011.

Ishaq. 2014. Pengantar Hukum Indonesia (PHI). Jakarta: Raja Grafindo Persada.

Ismail, Badruzzaman. 2012. Pedoman Peradilan Adat di Aceh untuk Peradilan Adat yang Adil dan Akuntabel. ed. 2. Banda Aceh: Majelis Adat Aceh.

Ismail, Badruzzaman. 2011. Singkronisasi dan Sinergitas Konsep Reusam Gampong dalam Mendukung Pengamalan Syari'at Islam di Banda Aceh, makalah disampaikan pada 25 Mei 2011.
Muhammad, R.A dan Khairizzaman. 2012. Konstelasi Syariat Islam di Era Global, Banda Aceh: Dinas Syari'at Islam.

Muhammad, R.A, dan Sumardi D. 2012. Kearifan Tradisional Lokal: Penyerapan Syariat Islam dalam Hukum Adat Aceh, Banda Aceh: Dinas Syariat Islam.

T. Djuned. 2008. Penerapan Sistem dan Asas-Asas Peradilan Hukum Adat dalam Penyelesaian Perkara (Sebagai Upaya Menggapai Kedamaian dan Ketertiban Masyarakat), dalam Pedoman Umum Adat Aceh (Peradilan dan Hukum Adat), Banda Aceh: Majelis Adat Aceh. 